\title{
ZEB1 Gene
}

National Cancer Institute

\section{Source}

National Cancer Institute. ZEB1 Gene. NCI Thesaurus. Code C105605.

This gene is involved in the transcriptional repression of interleukin 2. 